\title{
Cerium dioxide nanoparticles do not modulate the lipopolysaccharide-induced inflammatory response in human monocytes
}

This article was published in the following Dove Press journal:

International Journal of Nanomedicine

12 March 2012

Number of times this article has been viewed

\author{
Salik Hussain ${ }^{1, *}$ \\ Faris Al-Nsour ${ }^{1, *}$ \\ Annette B Rice' \\ Jamie Marshburn' \\ Zhaoxia Ji ${ }^{2}$ \\ Jeffery I Zink ${ }^{2}$ \\ Brenda Yingling' \\ Nigel J Walker ${ }^{3}$ \\ Stavros Garantziotis' \\ 'Clinical Research Unit, National \\ Institute of Environmental Health \\ Sciences/National Institute of Health, \\ Research Triangle Park, NC, ${ }^{2} \mathrm{UC}$ \\ Center for Environmental Implications \\ of Nanotechnology University of \\ California, Los Angeles, CA, \\ ${ }^{3}$ Division of National Toxicology \\ Program, National Institute of \\ Environmental Health Sciences/ \\ National Institute of Health, \\ Research Triangle Park, NC, USA \\ *Both are principal authors
}

Background: Cerium dioxide $\left(\mathrm{CeO}_{2}\right)$ nanoparticles have potential therapeutic applications and are widely used for industrial purposes. However, the effects of these nanoparticles on primary human cells are largely unknown. The ability of nanoparticles to exacerbate pre-existing inflammatory disorders is not well documented for engineered nanoparticles, and is certainly lacking for $\mathrm{CeO}_{2}$ nanoparticles. We investigated the inflammation-modulating effects of $\mathrm{CeO}_{2}$ nanoparticles at noncytotoxic concentrations in human peripheral blood monocytes.

Methods: $\mathrm{CD} 14^{+}$cells were isolated from peripheral blood samples of human volunteers. Cells were exposed to either 0.5 or $1 \mu \mathrm{g} / \mathrm{mL}$ of $\mathrm{CeO}_{2}$ nanoparticles over a period of 24 or 48 hours with or without lipopolysaccharide $(10 \mathrm{ng} / \mathrm{mL})$ prestimulation. Modulation of the inflammatory response was studied by measuring secreted tumor necrosis factor-alpha, interleukin-1beta, macrophage chemotactic protein-1, interferon-gamma, and interferon gamma-induced protein 10.

Results: $\mathrm{CeO}_{2}$ nanoparticle suspensions were thoroughly characterized using dynamic light scattering analysis (194 $\mathrm{nm}$ hydrodynamic diameter), zeta potential analysis ( $-14 \mathrm{mV})$, and transmission electron microscopy (irregular-shaped particles). Transmission electron microscopy of $\mathrm{CD}_{1} 4^{+}$cells exposed to $\mathrm{CeO}_{2}$ nanoparticles revealed that these nanoparticles were efficiently internalized by monocytes and were found either in vesicles or free in the cytoplasm. However, no significant differences in secreted cytokine profiles were observed between $\mathrm{CeO}_{2}$ nanoparticletreated cells and control cells at noncytotoxic doses. No significant effects of $\mathrm{CeO}_{2}$ nanoparticle exposure subsequent to lipopolysaccharide priming was observed on cytokine secretion. Moreover, no significant difference in lipopolysaccharide-induced cytokine production was observed after exposure to $\mathrm{CeO}_{2}$ nanoparticles followed by lipopolysaccharide exposure.

Conclusion: $\mathrm{CeO}_{2}$ nanoparticles at noncytotoxic concentrations neither modulate pre-existing inflammation nor prime for subsequent exposure to lipopolysaccharides in human monocytes from healthy subjects.

Keywords: cerium dioxide, nanoparticle, nanomedicine, inflammation, human monocyte, lipopolysaccharides

\section{Introduction}

Nanomedicine is expected to benefit from cerium dioxide $\left(\mathrm{CeO}_{2}\right)$ nanoparticle use in antioxidant therapy, ${ }^{1}$ neuroprotection, ${ }^{2}$ radioprotection, ${ }^{3}$ and ocular protection. ${ }^{4}$ Apart from these nanomedicinal uses, various industrial applications of $\mathrm{CeO}_{2}$ nanoparticles include catalysis, ${ }^{5}$ ultraviolet absorbance,,${ }^{6,7}$ oxygen sensing, ${ }^{8}$ solar and fuel cells, ${ }^{9}$ and polishing (for glasses, lenses, television tubes, fuel cells, and precision optics). ${ }^{10}$ Moreover, $\mathrm{CeO}_{2}$ nanoparticles have significant environmental health significance due to their widespread use as a diesel fuel additive. Indeed, it has been documented that addition of $\mathrm{CeO}_{2}$ to diesel decreases fuel consumption by $5 \%-8 \%$ and
Correspondence: Salik Hussain Unit, National Institute of Environmental Health Sciences, Research Triangle Park, 27709 Durham, NC, USA

$\mathrm{Tel}+\mathrm{I} 9193164806$

$\mathrm{Fax}+19195419854$

Email salik.hussain@nih.gov 
emission of combustion-derived nanoparticles and unburned hydrocarbons by up to $15 \% .{ }^{11,12}$ However, the accompanying release of $\mathrm{CeO}_{2}$ nanoparticles into the environment could exert unexpected health effects. ${ }^{13}$ For this reason, the Organization for Economic Cooperation and Development has included $\mathrm{CeO}_{2}$ nanoparticles in the priority list of nanomaterials requiring urgent evaluation. ${ }^{14}$

Most human diseases are associated with local or systemic inflammatory responses. Moreover, exposure to environmental proinflammatory agents is ubiquitous; for example, we are all exposed to bacterial lipopolysaccharides, either through ingestion (contaminated food or water) or inhalation (house dust, particulate matter, diesel exhaust particles). Furthermore, many epidemiological and experimental studies have shown that individuals with pre-existing inflammatory conditions are more prone to the adverse effects of environmental injury. ${ }^{15-17}$ Indeed, aggravation of pre-existing inflammation has been documented after exposure to particulate air pollution and various types of nanoparticles. ${ }^{18-21}$

This study was designed to investigate the inflammationmodulating effects of $\mathrm{CeO}_{2}$ nanoparticles in human peripheral blood monocytes at noncytotoxic exposure concentrations. The proposed uses of $\mathrm{CeO}_{2}$ nanoparticles in nanomedicine make peripheral blood monocytes important target cells at the portal of entry of nanoparticles into the human body. These cells are an essential link between the adaptive and innate immune responses because they develop into various forms of antigen-presenting cells (macrophages, dendritic cells). We show here that noncytotoxic exposures to $\mathrm{CeO}_{2}$ nanoparticles do not prime or aggravate pre-existing lipopolysaccharide-induced inflammation.

\section{Materials and methods}

\section{Study subjects and isolation of cells}

This study was approved by the National Institute of Environmental Health Sciences institutional review board. Adult human volunteers without any history of a chronic medical condition (hepatitis B, hepatitis C, or human immunodeficiency virus) and currently not taking any type of medication were recruited to the National Institute of Environmental Health Sciences Clinical Research Unit. The demographics of the study population are shown in Table 1. Recruited volunteers underwent phlebotomy, and up to $300 \mathrm{~mL}$ of whole blood were withdrawn from an antecubital vein into citrated tubes. Mononuclear fraction was isolated using gradient centrifugation, and $\mathrm{CD} 14^{+}$cells were purified using magnetic beads according to the manufacturer's recommendations (Miltenyi Biotec, Boston, MA). By this method, 95\%-99\%
Table I Population demographics

\begin{tabular}{llll}
\hline $\begin{array}{l}\text { Age } \\
\text { (years) }\end{array}$ & $\begin{array}{l}\text { Sex } \\
\text { (male/female) }\end{array}$ & $\begin{array}{l}\text { Race } \\
\text { (African American/ } \\
\text { Asian/Caucasian) }\end{array}$ & Medication \\
\hline $44 \pm 12$ & $21 / 16$ & $8 / 2 / 27$ & None \\
\hline
\end{tabular}

viable pure human monocytes were obtained, confirmed by flow cytometry and cytospin preparations.

\section{Cells and culture conditions}

After isolation, the cells were seeded in 24-well cell culture plates $\left(400,000\right.$ cells per well) in X-vivo ${ }^{\text {TM }}$ cell culture medium (Lonza, Walkersville, MD) supplemented with 1\% human serum and antibiotics ( $1 \%$ solution of penicillin $100 \mu \mathrm{g} / \mathrm{mL}$ and streptomycin $100 \mu \mathrm{g} / \mathrm{mL}$; Invitrogen Carlsbad, CA) and incubated at $37^{\circ} \mathrm{C}, 5 \% \mathrm{CO}_{2}$, and $95 \%$ relative humidity for 2 hours (to allow sufficient time for attachment of cells). After cell attachment, the cell culture medium was aspirated and the cells were washed thoroughly with fresh medium to remove unattached cells. The cells were then incubated in fresh prewarmed medium containing the desired doses of nanoparticles or lipopolysaccharides for the different time intervals ( 24 or 48 hours).

\section{Nanoparticles}

$\mathrm{CeO}_{2}$ nanoparticles were obtained from Meliorum Technologies (Rochester, NY) and characterized in the Center for Environmental Implications of Nanotechnology, University of California. Studied characteristics included shape/diameter (transmission electron microscopy), crystal structure (X-ray diffraction analysis), surface area (Brunauer-Emmitt-Teller method), suspension behavior, hydrodynamic diameter, and size distribution (dynamic light scattering), zeta potential (ZetaSizer Nano; Malvern Instruments, Westborough, MA), purity (thermogravimetric analysis), and bacterial endotoxins (limulus amebocyte lysate assay). Dynamic light scattering analysis of the $\mathrm{CeO}_{2}$ nanoparticle suspensions (at $1 \mu \mathrm{g} / \mathrm{mL}$ ) in cell culture medium was done to determine the size distribution. A nanoparticle stock solution $(1 \mathrm{mg} / \mathrm{mL})$ was prepared in water and stored at $4^{\circ} \mathrm{C}$ in a refrigerator. All exposure suspensions were freshly prepared from this stock solution after sonication at three pulses of 20 seconds at $235 \mathrm{~W}$ each with a 5-second pause using a Mesonix S 4000 cup horn sonicator (Qsonica LLC, Newtown, CT). After sonication, the particles were suspended in cell culture medium and used to expose cells within 5 minutes after vortexing.

These are the best known commercially available $\mathrm{CeO}_{2}$ nanoparticles which have been widely explored in various 
fields (toxicology, biology, nanotechnology) and have an excellent publication record. From an environmental perspective, study of these particles is very valid because the particles and their aggregates lie within the range of respirable particles (less than $3 \mu \mathrm{m}$ ) which can deposit in the alveolar regions of the lungs.

\section{Experimental design}

A low effective dose of lipopolysaccharides (Escherichia coli O111:B4, $10 \mathrm{ng} / \mathrm{mL}$ ) was used to induce an inflammatory response in the cells. The total duration of the experiments was fixed to either 24 or 48 hours and the ability of the nanoparticles to modulate pre-existing inflammation or to prime for subsequent inflammation was assessed. A graphical description of the protocols is given in Figure 1. To assess the ability of the nanoparticles to modulate pre-existing inflammation, the cells were incubated with lipopolysaccharides for 16 hours and then exposed to $\mathrm{CeO}_{2}$ nanoparticles for 8 hours (24-hour protocol) or 32 hours (48-hour protocol). On the other hand, to assess the ability of the nanoparticles to prime for subsequent exposure to inflammatory agents, the cells were exposed to $\mathrm{CeO}_{2}$ nanoparticles for 16 hours and then exposed to lipopolysaccharides for 8 hours or 32 hours (for the 24-hour and 48-hour protocols, respectively).

\section{Transmission electron microscopy for nanoparticle-cell interaction}

Cells were grown in two-chamber cell culture slides and treated with 0.5 or $1 \mu \mathrm{g} / \mathrm{mL} \mathrm{CeO}_{2}$ nanoparticles for 24 hours. The cells were fixed in 3\% glutaraldehyde and processed for transmission electron microscopic analysis. Thin sections

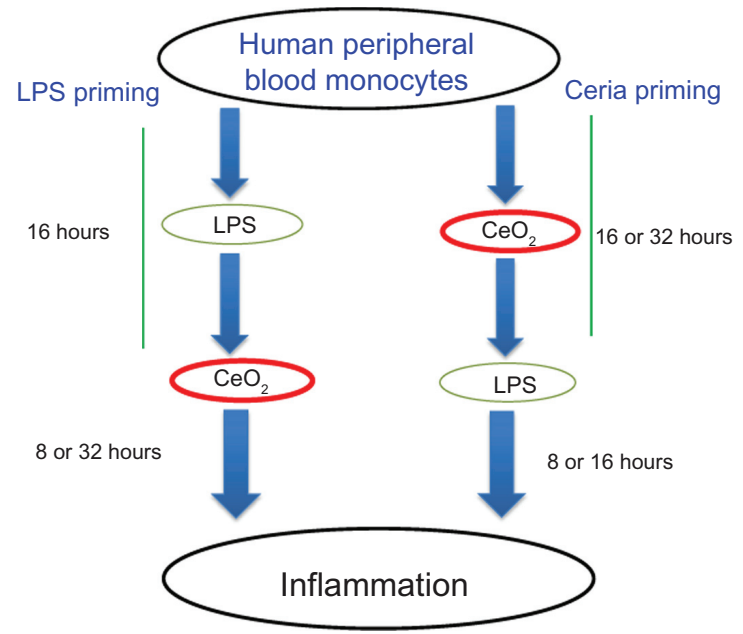

Figure I Schematic presentation of the experimental design used in the present study to elaborate the inflammation-modulating effects of $\mathrm{CeO}_{2}$ nanoparticles. Abbreviation: LPS, lipopolysaccharides.
(60-90 nm) were cut and placed on Formvar copper grids then stained with uranyl acetate and lead citrate. After staining, sections were examined on a FEI Tecnai $110 \mathrm{kV}$ microscope at $80 \mathrm{kV}$ and digital photomicrographs were taken.

\section{Toxicity analysis}

A propidium iodide incorporation assay was performed to evaluate membrane integrity and cytotoxicity. Briefly, cells were trypsinated after 24-hour or 48-hour exposures using trypsin-EDTA. The action of trypsin was inhibited using 10\% fetal bovine serum, and the cells were centrifuged at $960 \mathrm{rpm}$ for 6 minutes. Cells were resuspended in $500 \mu \mathrm{L}$ of warm cell culture medium containing $2.5 \mu \mathrm{g} / \mathrm{mL}$ of propidium iodide. Analysis was performed on a FACSAria II (BD Biosciences, Franklin Lakes, NJ) instrument at $488 \mathrm{~nm}$ excitation and $610 \mathrm{~nm}$ emission wavelengths. After elimination of cellular debris, at least 10,000 cells were analyzed to determine the percentage of propidium iodide-positive cells.

\section{Measurement of cytokines}

At the end of the desired incubation time, the supernatants were recovered, centrifuged at $10,000 \mathrm{~g}$ for 15 minutes at $4^{\circ} \mathrm{C}$, and stored at $-80^{\circ} \mathrm{C}$ till further analysis. The concentration of tumor necrosis factor alpha (TNF- $\alpha$ ) was evaluated using a commercially available human enzyme-linked immunosorbent assay kit (R\&D Systems, Minneapolis, MN) according to the manufacturer's recommendations. The concentrations of interleukin-1beta (IL-1 $\beta$ ), macrophage chemotactic protein-1, IP-10, and interferon-gamma (INF- $\gamma$ ) were determined using the BD Bioplex assay system (BD Biosciences).

\section{Statistical analysis}

Data are presented as the mean \pm standard error of the mean and were analyzed by analysis of variance, followed by Tukey's test using GraphPad (GraphPad Prism 4.01, GraphPad Software Inc, San Diego, CA). A level of $P<0.05$ (two-tailed) was considered to be statistically significant.

\section{Results}

\section{Nanoparticle characteristics}

The nanoparticle characteristics are presented in Table 2 and Figure 2. Transmission electron microscopic analysis revealed that the $\mathrm{CeO}_{2}$ nanoparticles were irregular in shape and tended to aggregate (Figure 2A). The X-ray diffraction analysis pattern is shown in Figure 2B, demonstrating that the particles are highly crystalline and all peaks could be indexed to cubic fluorite $\mathrm{CeO}_{2}$. Dynamic light scattering analysis revealed that the $\mathrm{CeO}_{2}$ nanoparticles $(1 \mu \mathrm{g} / \mathrm{mL})$ 
Table 2 Particle characteristics

\begin{tabular}{|c|c|c|c|}
\hline $\begin{array}{l}\text { Physicochemical } \\
\text { properties }\end{array}$ & $\begin{array}{l}\text { Characterization } \\
\text { techniques }\end{array}$ & Unit & $\mathrm{CeO}_{2}$ \\
\hline \multirow[t]{2}{*}{ Primary size } & TEM/SEM & $\mathrm{nm}$ & $10-30$ \\
\hline & XRD & $\mathrm{nm}$ & 7 \\
\hline \multicolumn{4}{|l|}{ Particle size } \\
\hline Ex-vivo medium & Malvern zeta-sizer & $\mathrm{nm}$ & 96 \\
\hline Water & & & 231 \\
\hline \multirow[t]{2}{*}{ Phase and structure } & XRD & & $100 \%$ ceria \\
\hline & & & cubic \\
\hline Morphology & TEM & & Irregular \\
\hline Surface area & BET & $m^{2} g^{-1}$ & 93.8 \\
\hline $\mathrm{pH}_{\text {iep }}$ (isoelectric point) & ZetaPALS & & 7.8 \\
\hline \multicolumn{4}{|l|}{ Zeta potential } \\
\hline Ex-vivo medium & ZetaPALS & $\mathrm{mV}$ & -13 \\
\hline Water & & & 19.1 \\
\hline Purity & TGA* & $\mathrm{Wt} \%$ & 95.41 \\
\hline Moisture content & TGA & $\mathrm{Wt} \%$ & 4.01 \\
\hline Acid content & TGA & $\mathrm{Wt} \%$ & 0.85 \\
\hline
\end{tabular}

Note: *Thermogravimetric analysis.

suspended as a single ( $96 \mathrm{~nm}$ size) population in $\mathrm{x}$-vivo cell culture media supplemented with $1 \%$ heat inactivated human serum. Further, these particles had $-13 \mathrm{mV}$ zeta potentials in the same suspension.

\section{$\mathrm{CeO}_{2}$ nanoparticles are internalized by human monocytes}

Transmission electron microscopic analysis of nanoparticlecell interactions indicated that the $\mathrm{CeO}_{2}$ nanoparticles were taken up by human monocytes either in vesicles/phagosomes (mixed with the other debris) or were free in the cytoplasm (Figure 3).

\section{$\mathrm{CeO}_{2}$ nanoparticles induce cytotoxicity}

The cytotoxic potential of $\mathrm{CeO}_{2}$ nanoparticles was tested using propidium iodide staining (Figure 4). Figure 4A shows the cytotoxic response after exposure to different doses of $\mathrm{CeO}_{2}$ nanoparticles. We demonstrated that $\mathrm{CeO}_{2}$ nanoparticles induce a cytotoxic response at doses $>1 \mu \mathrm{g} / \mathrm{mL}$ (Figure 4A). We therefore decided to use only the lower doses ( $\leq 1 \mu \mathrm{g} / \mathrm{mL}$ ) for our inflammatory response experiments. We confirmed that addition of $10 \mathrm{ng} / \mathrm{mL}$ lipopolysaccharides to these doses of $\mathrm{CeO}_{2}$ did not alter cytotoxicity (Figure 4B).

\section{$\mathrm{CeO}_{2}$ nanoparticles do not modulate inflammatory response to lipopolysaccharides}

The ability of $\mathrm{CeO}_{2}$ nanoparticles to modulate or prime the inflammatory response to lipopolysaccharides was assessed using the protocol described in Figure 1. As presented in
Figure 5, we did not find any significant difference in the production of TNF- $\alpha$, a proinflammatory cytokine, after $\mathrm{CeO}_{2}$ nanoparticle exposure. A similar pattern was observed for IL-1 $\beta$ production (Figure 6). IFN- $\gamma$ and IP-10 also showed a similar trend, and the results are presented in Table 3 . Macrophage chemotactic protein-1 production was increased by lipopolysaccharide exposure only at 24 hours and this increase was no longer detected at 48 hours.

\section{Discussion}

Nanotechnology has shown promising potential to improve the quality of everyday life and has led to the production of a variety of novel materials for industrial, consumer product, and medicinal applications. However, there is a lack of adequate data about the effects of these nanomaterials on human health and the environment. In particular, the effects of these novel materials on susceptible populations (with pre-existing health issues) are rarely addressed. Evaluation of such effects becomes even more pertinent when considering the proposed use of nanomaterials in the medical sector. This experimentation aimed at: elucidating the inflammatory potential of $\mathrm{CeO}_{2}$ nanoparticles; evaluating the possibility of aggravation of a pre-existing inflammatory response after exposure to $\mathrm{CeO}_{2}$ nanoparticles; and exploration of the ability of $\mathrm{CeO}_{2}$ nanoparticles to prime for subsequent exposure to an inflammatory agent. Our results indicate that $\mathrm{CeO}_{2}$ nanoparticles do not significantly change the lipopolysaccharide-induced inflammatory responses of peripheral blood monocytes at noncytotoxic doses. Moreover, $\mathrm{CeO}_{2}$ nanoparticles did not prime human monocytes for subsequent exposure to lipopolysaccharides.

Controversy exists in the published literature about the inflammatory effects of $\mathrm{CeO}_{2}$ nanoparticles. Hirst et al reported anti-inflammatory effects by demonstrating reduction of inducible nitric oxide expression in J774A.1 macrophages ${ }^{22}$ and Niu et al reported suppression of inflammatory mediators (macrophage chemotactic protein-1, IL-6, and TNF- $\alpha$ ) production by $\mathrm{CeO}_{2}$ nanoparticles in a murine cardiomyopathy model. ${ }^{23}$ Moreover, $\mathrm{CeO}_{2}$ nanoparticles have been reported to reduce oxidative signaling and cell death induced by cigarette smoke, diesel exhaust, and hydrogen peroxide. ${ }^{24-26}$ In contrast, other in vitro and in vivo experiments suggest that $\mathrm{CeO}_{2}$ nanoparticles produce inflammation, reactive oxygen species, lipid peroxidation, liver and lung damage, acute and chronic fibrotic effects, and altered macrophage phenotypes. ${ }^{27-31}$ Variation in target species/ cell type, experimental design (exposure concentration and duration) and nanoparticle characteristics (shape, size, purity, 
A
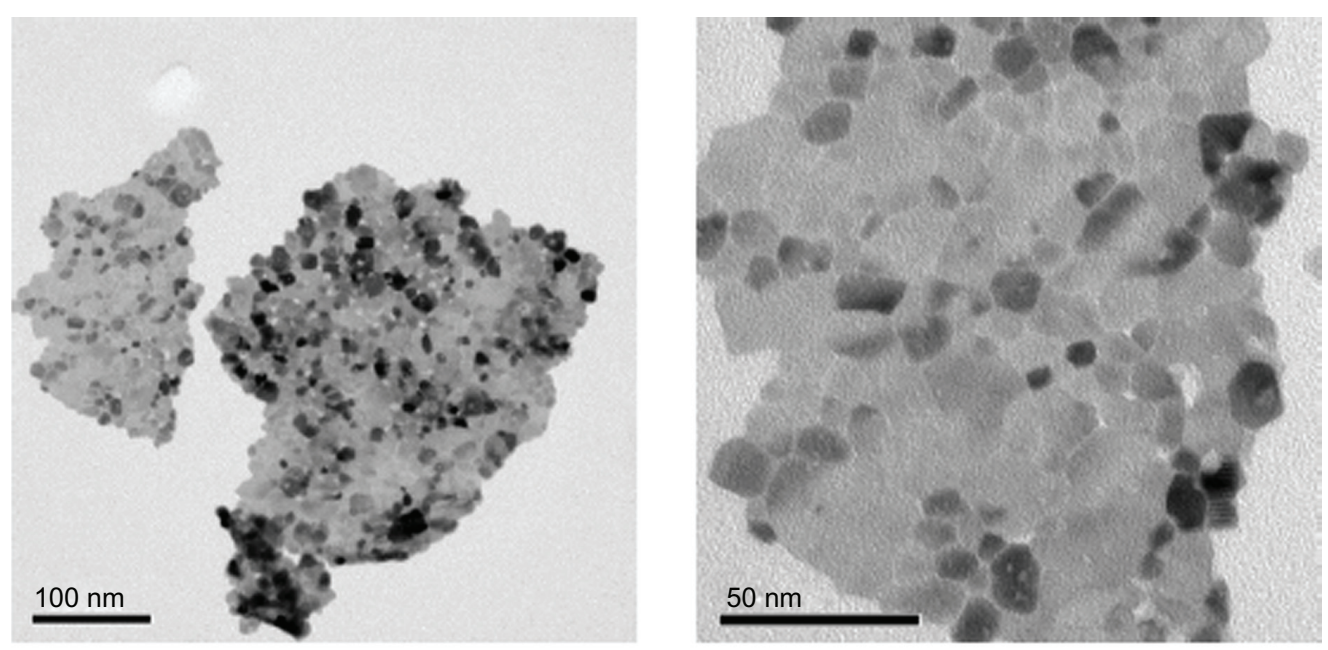

B
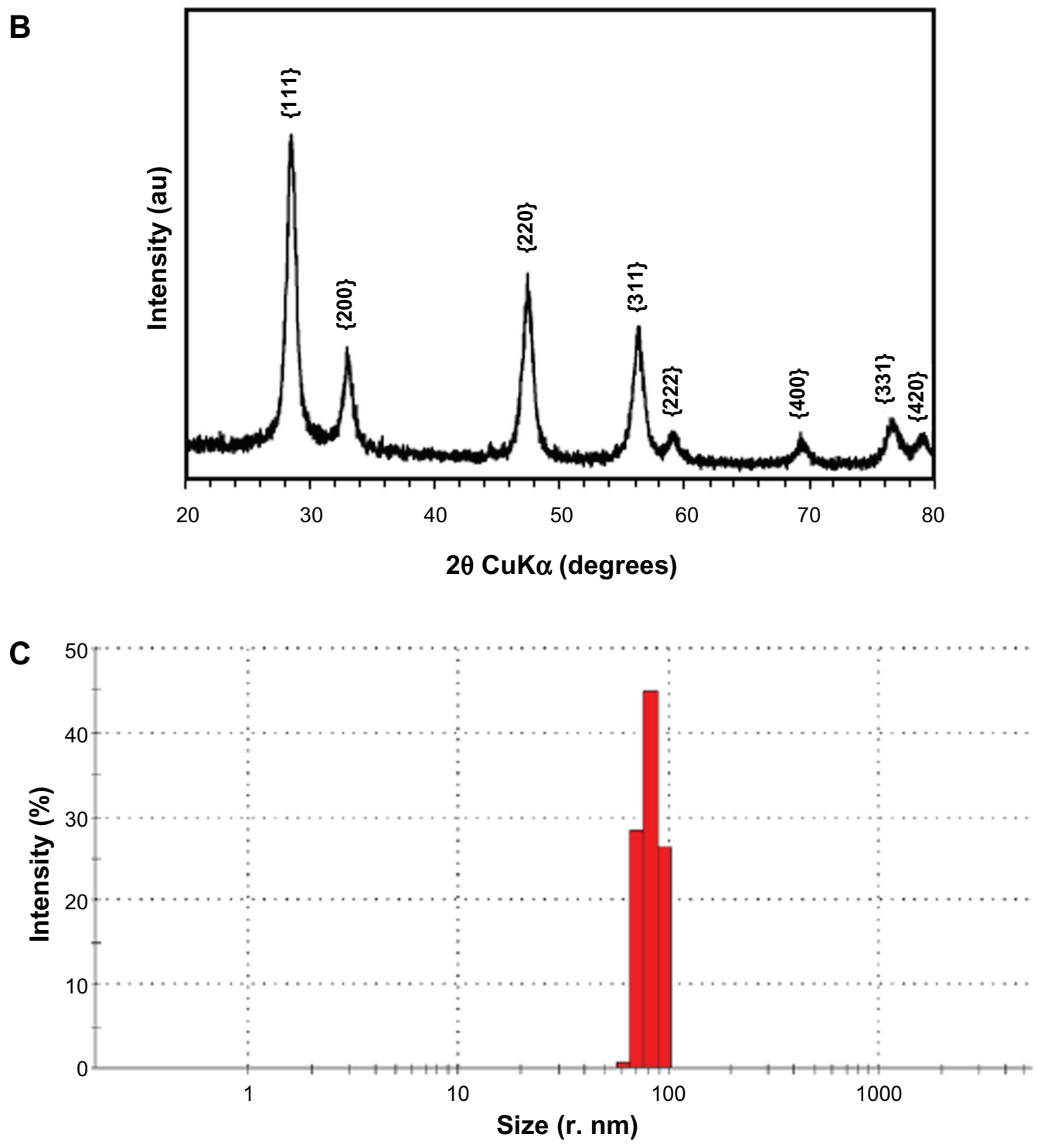

Figure 2 Physicochemical characterization of $\mathrm{CeO}_{2}$ nanoparticles. (A) Transmission electron microscopic images of nanoparticle suspensions (low and high magnification). (B) X-ray diffraction analysis pattern of $\mathrm{CeO}_{2}$ nanoparticles. (C) Dynamic light scattering analysis of $\mathrm{CeO}_{2}$ nanoparticles suspension $(\mathrm{I} \mu \mathrm{g} / \mathrm{mL})$ in ex-vivo cell culture medium performed using Malvern Zetasizer Nano. 
A

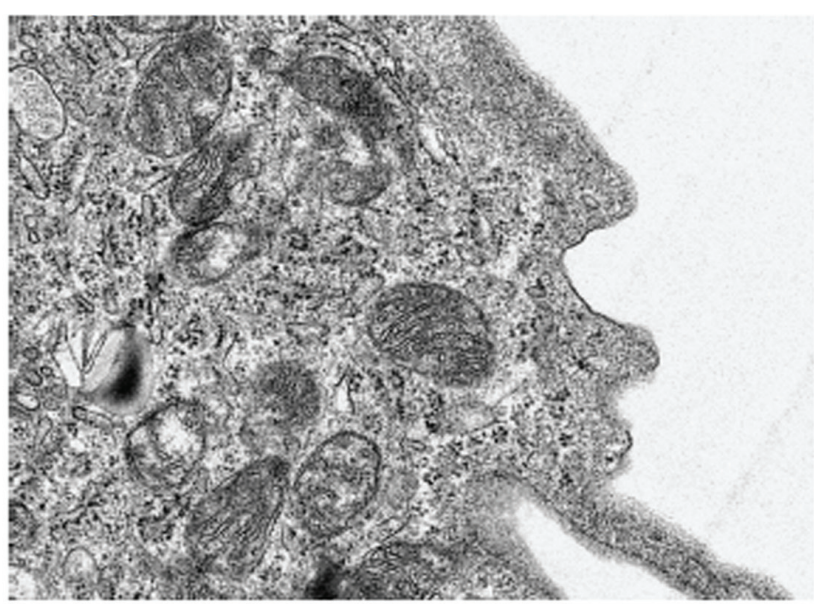

B

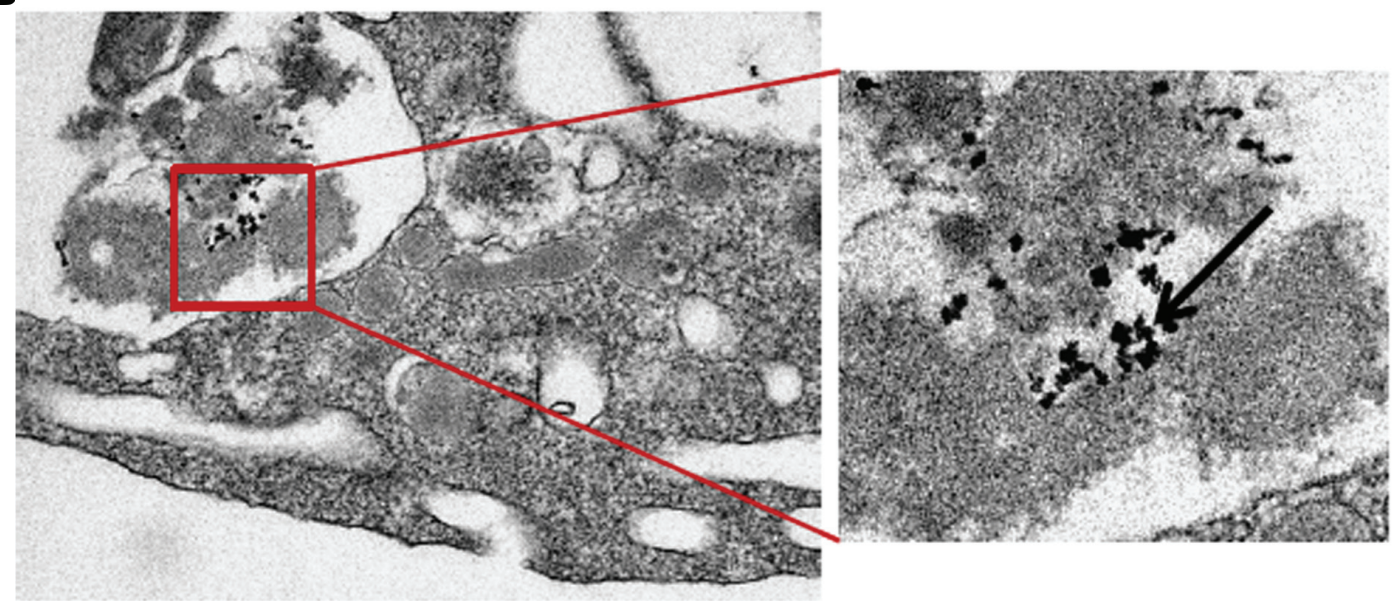

C

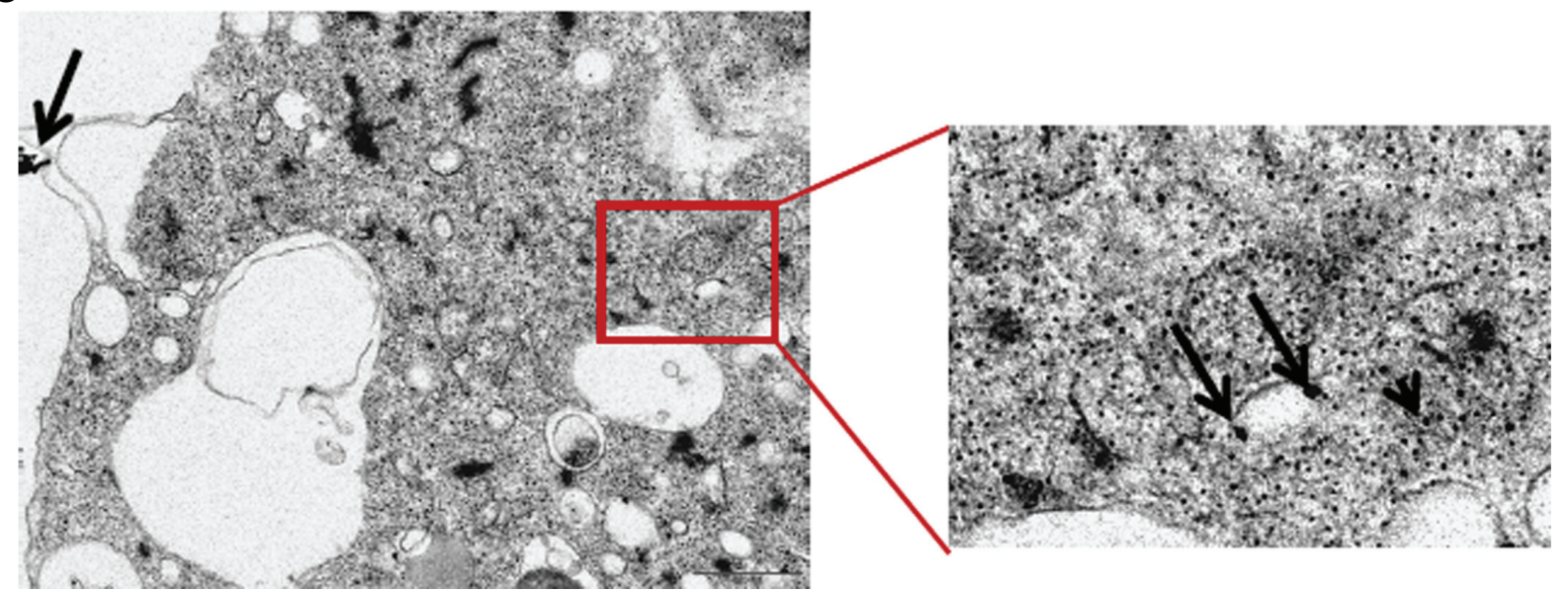

Figure 3 Transmission electron microscopic analysis of $\mathrm{CeO}_{2}$ nanoparticle-treated human monocytes. Cells were treated with $(\mathbf{A}) \mathrm{media},(\mathbf{B}) 0.5 \mu \mathrm{g} / \mathrm{mL}$, and $(\mathbf{C}) \mathrm{I} \mu \mathrm{g} / \mathrm{mL}$ $\mathrm{CeO}_{2}$ nanoparticles for 24 hours and ultrastructural changes were observed.

Note: Arrows point to the particle aggregates. 
A
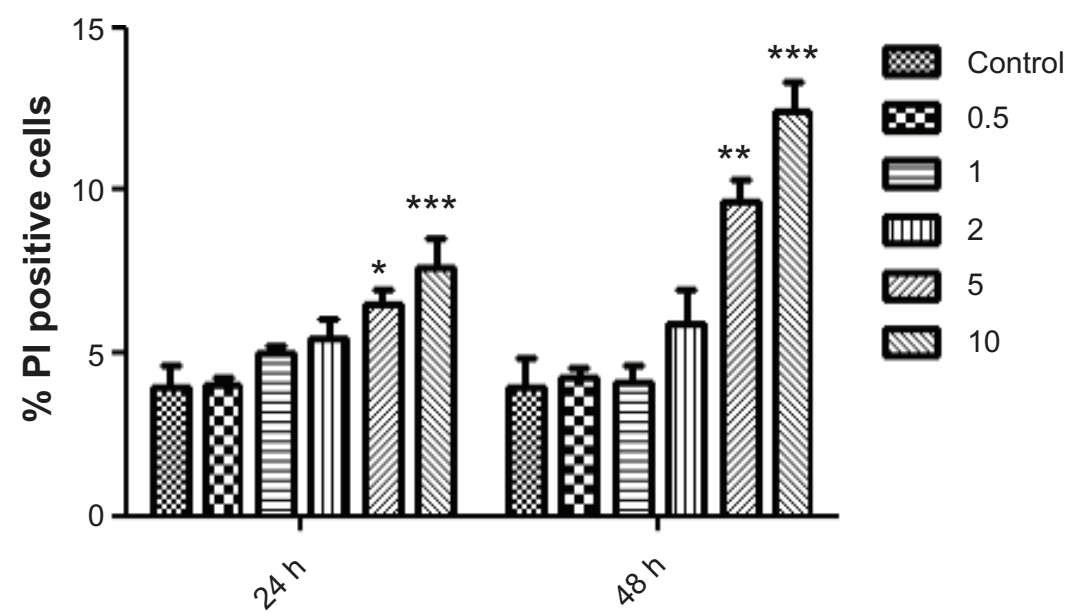

$x^{8}$
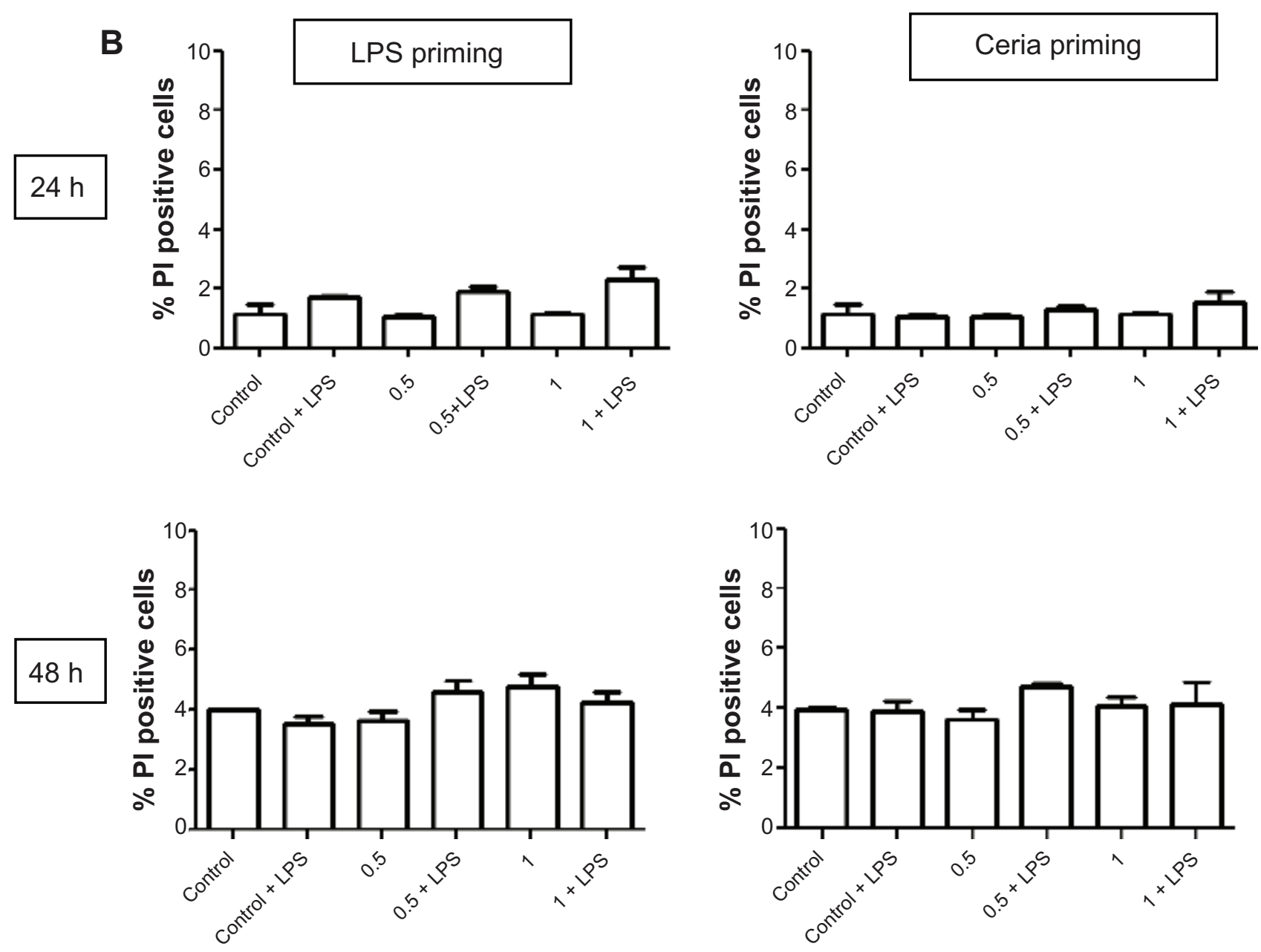

Figure 4 Evaluation of human monocyte cytotoxicity after exposure to $\mathrm{CeO}_{2}$ nanoparticles. (A) Cells were treated with different doses of nanoparticles $(0.5-10 \mu \mathrm{g} / \mathrm{mL})$ for 24 or 48 hours, stained with propidium iodide for membrane integrity, and analyzed using flow cytometry. (B) Cells were exposed to noncytotoxic doses of CeO, nanoparticles either in the presence or absence of lipopolysaccharides for 24 or 48 hours as shown in Figure I, stained with propidium iodide and analyzed using flow cytometry.

Notes: Data are presented as the mean \pm standard error of the mean and analyzed by analysis of variance, followed by Tukey's post hoc test. $\mathrm{n}=5$; $* P<0.05$; $* * P<0.0$; $* * * P<0.001$.

Abbreviations: PI, propidium iodide; LPS, lipopolysaccharides. 

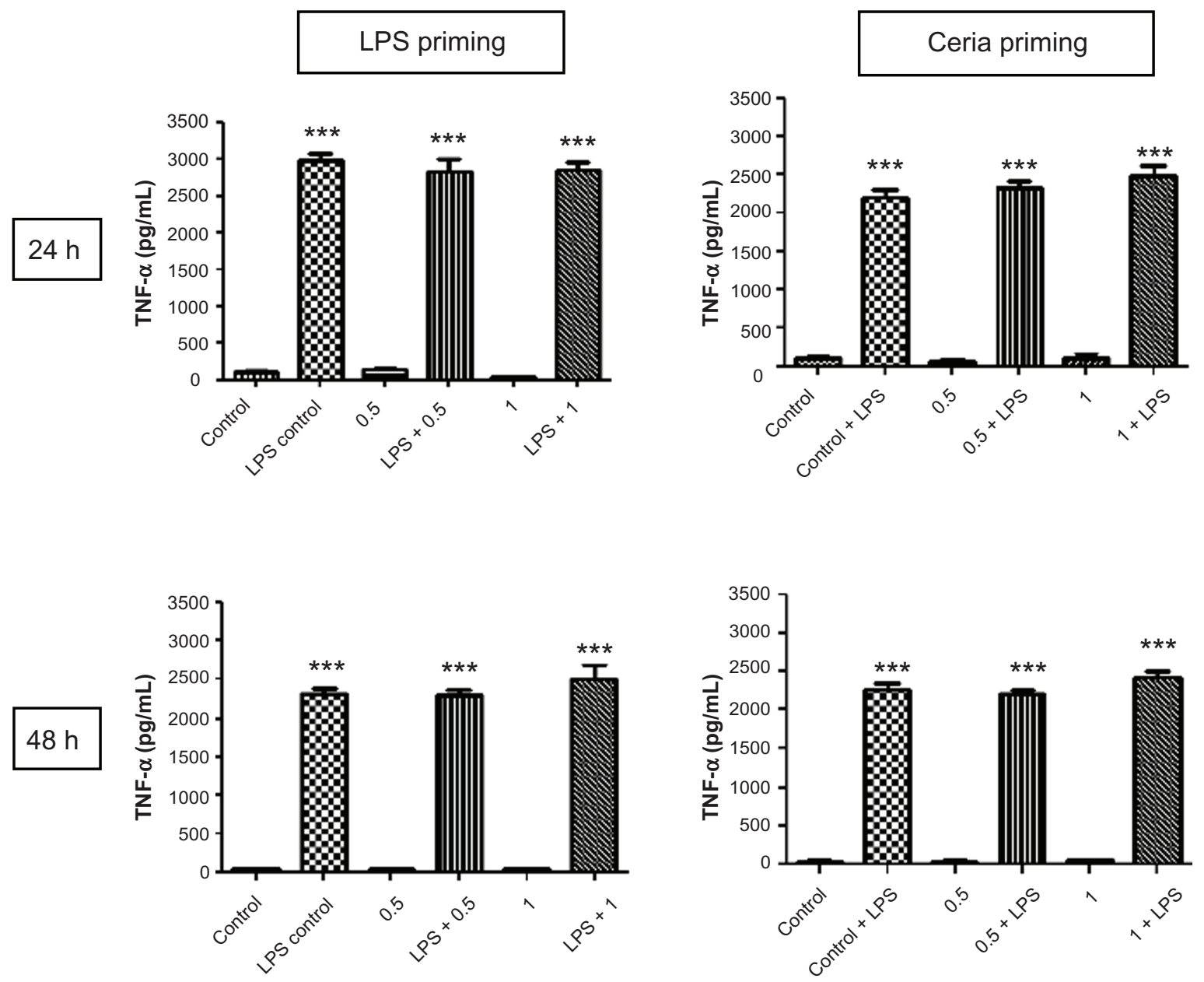

Figure 5 Evaluation of inflammation modulating ability of $\mathrm{CeO}_{2}$ nanoparticles in human monocytes. Cells were treated according to the protocol presented in Figure I and the amount of TNF- $\alpha$ in cell culture supernatants was analyzed by enzyme-linked immunosorbent assay according to the manufacturer's recommendations.

Notes: Data are presented as the mean \pm standard error of the mean and analyzed by analysis of variance, followed by Tukey's post hoc test. $\mathrm{n}=5-10$; $* * * P<0.001$.

Abbreviations: LPS, lipopolysaccharides; TNF- $\alpha$, tumor necrosis factor-alpha.

agglomeration, and surface modifications) could be possible reasons for these differences and make cross-study comparisons difficult. Further, $\mathrm{CeO}_{2}$ nanoparticles can be prepared by different methods that lead to differences in relative proportions of $\mathrm{Ce}^{3+} / \mathrm{Ce}^{4+}$ ions (one of the reasons proposed for $\mathrm{CeO}_{2}$ nanoparticle-induced reactive oxygen species scavenging). ${ }^{32}$ Nevertheless, we did not observe any significant differences in cytokine release of human immune cells after exposure to noncytotoxic doses of $\mathrm{CeO}_{2}$ nanoparticles.

The present study is unique in the sense that it addresses the question of pre-existing inflammatory conditions in human cells which are likely to exist in the event of therapeutic application of $\mathrm{CeO}_{2}$ nanoparticles. Indeed, it has already been suggested that during the development of therapeutic nanomaterials, their biocompatibility should also be evaluated in the presence of other agonists such as lipopolysaccharides. ${ }^{33}$ Moreover, studies in mice and in cell lines may not accurately predict nanoparticle-elicited responses in primary human cells. Lastly, $\mathrm{CeO}_{2}$ nanoparticle-induced protective effects have been reported in oxidative stress-dependent processes, but no attempt has been made to explore the possibility of similar effects on oxidative stress-independent mechanisms (such as lipopolysaccharide-induced inflammatory responses). Our study addresses these gaps in our knowledge. Our data suggest that pre-existing inflammation does not seem to alter the response to $\mathrm{CeO}_{2}$ nanoparticles significantly. On the other hand, we did not find any beneficial effect of $\mathrm{CeO}_{2}$ nanoparticles on lipopolysaccharide-induced cytokine release, suggesting that the previously reported antioxidant effects of $\mathrm{CeO}_{2}$ nanoparticles in macrophages may be limited in their scope of action, and do not extend to a general downregulation of the inflammatory response.

We did find $\mathrm{CeO}_{2}$ nanoparticle internalization by human monocytes, either in the form of vesicles or free in cytoplasm. 

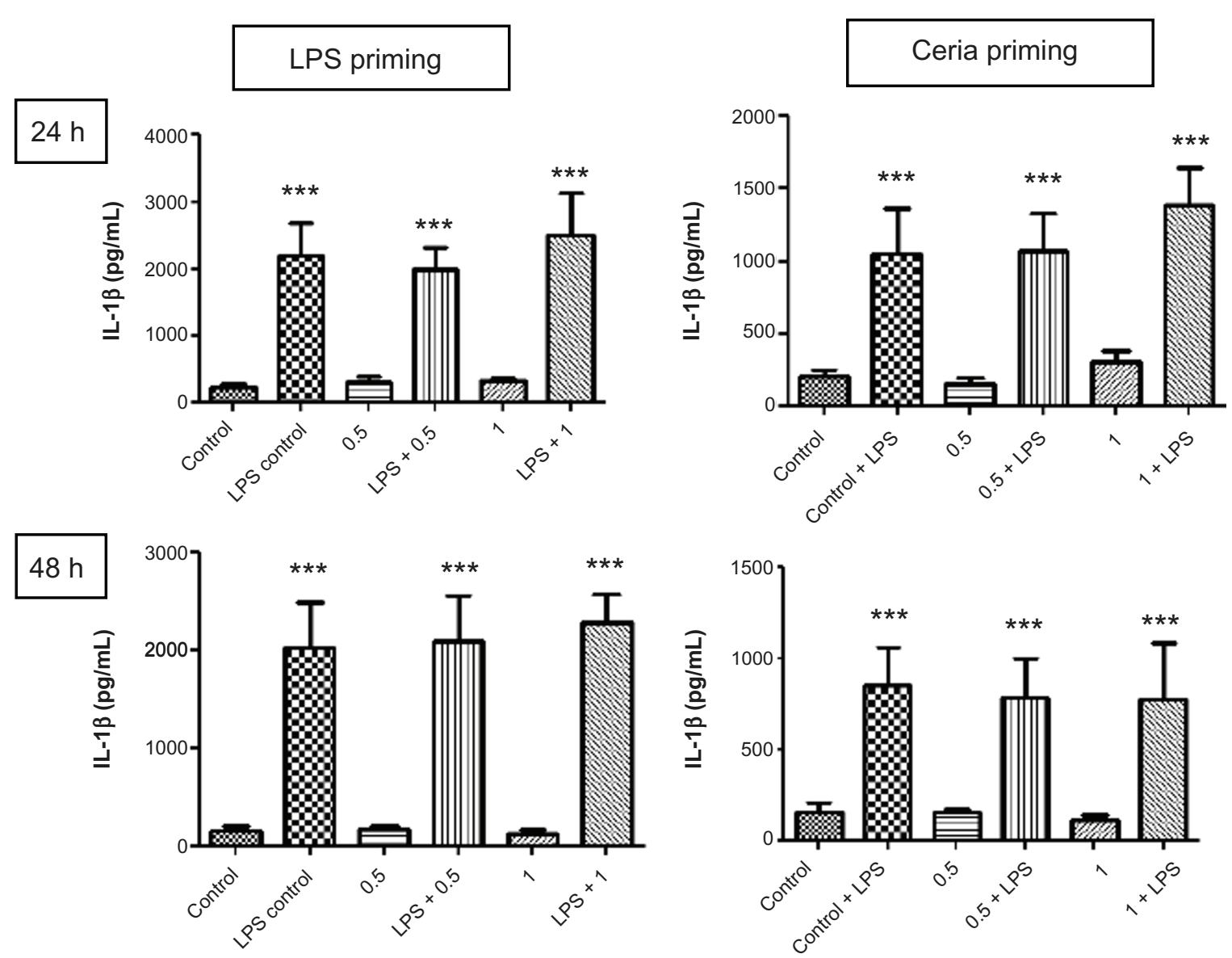

Figure 6 Evaluation of inflammation-modulating ability of $\mathrm{CeO}_{2}$ nanoparticles in human monocytes. Cells were treated according to the protocol presented in Figure I and the amount of IL-I $\beta$ in cell culture supernatants was analyzed by the Bioplex assay according to the manufacturer's recommendations.

Notes: Data are presented as the mean \pm standard error of the mean and analyzed by analysis of variance, followed by Tukey's post hoc test. $\mathrm{n}=5-\mathrm{I} 0$; $* * * P<0.00 \mathrm{I}$.

Abbreviations: IL-I $\beta$, tumor necrosis factor-alpha; LPS, lipopolysaccharides.

These results are in agreement with previous studies reporting endocytosis of $\mathrm{CeO}_{2}$ nanoparticles into cells..$^{34,35}$ These results indicate that $\mathrm{CeO}_{2}$ nanoparticles have good biocompatibility at the tested concentrations and their presence inside the cells did not influence the production of the cytokines studied.

We and others have previously shown that nanoparticles can adsorb cytokines and other biologically significant proteins (for example, enzymes) onto their surfaces and thus may interfere with accurate assessment of their inflammatory potential. ${ }^{36-38}$ We checked the possibility of TNF- $\alpha$ binding by incubating the nanoparticles with a known concentration of TNF- $\alpha$ for 24 or 48 hours and reanalyzing the concentrations of cytokines by enzyme-linked immunosorbent assay. We did not find any difference between untreated and nanoparticle-treated samples, indicating that $\mathrm{CeO}_{2}$ nanoparticles did not adsorb cytokines.

Our study does have certain limitations. These include use of lipopolysaccharide priming (which can skew the inflammatory responses towards Th1) and use of Th1 cytokines only to assess inflammation. However, this does not limit the scope of our study because lipopolysaccharide exposure is well described and one of the best environmentally

Table 3A Cytokine concentrations without priming

\begin{tabular}{|c|c|c|c|c|c|c|}
\hline & \multicolumn{2}{|l|}{ INF- $\gamma$} & \multicolumn{2}{|l|}{ IP-IO } & \multicolumn{2}{|l|}{ MCP-I } \\
\hline & $24 \mathrm{~h}$ & $48 \mathrm{~h}$ & $24 \mathrm{~h}$ & $48 \mathrm{~h}$ & $24 \mathrm{~h}$ & $48 h$ \\
\hline Control & $18.4 \pm 1.7$ & $17.6 \pm 1.7$ & $129.8 \pm 24.06$ & $28.79 \pm 6.33$ & $875.8 \pm 167.2$ & $3511 \pm 870.8$ \\
\hline $\mathrm{CeO}_{2} 0.5 \mu \mathrm{g} / \mathrm{mL}$ & $17.7 \pm 1.5$ & $20.5 \pm 2.3$ & $106.8 \pm 22.7$ & $38.25 \pm 10.7$ & $815.6 \pm 116.0$ & $4219 \pm 929.4$ \\
\hline $\mathrm{CeO}_{2} \mathrm{I} \mu \mathrm{g} / \mathrm{mL}$ & $18 \pm 1.5$ & $17.0 \pm 2.0$ & $\mid 39.1 \pm 29.2$ & $46.0 \pm 9.5$ & $1336 \pm 573.9$ & $4287 \pm 912$ \\
\hline
\end{tabular}

Abbreviations: INF- $\gamma$, interferon-gamma; IP-10, interferon gamma-induced protein 10; MCP-I, macrophage chemotactic protein-I. 


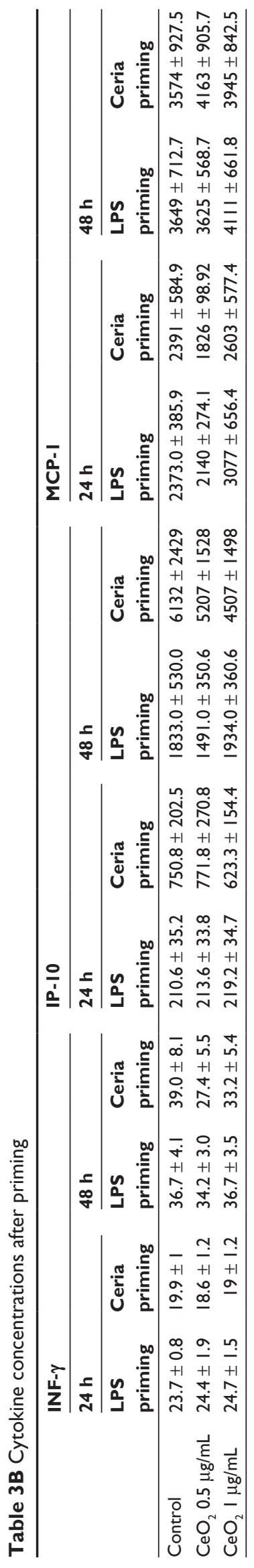

relevant models available in which to conduct inflammation modulation studies. More in vivo studies are in progress to study Th1/Th2 polarization of responses and to elaborate the possibilities of modulation of allergic lung inflammation after exposure to $\mathrm{CeO}_{2}$ nanoparticles.

\section{Conclusion}

Overall, our results suggest that, under noncytotoxic exposure conditions, $\mathrm{CeO}_{2}$ nanoparticles neither modulate nor prime for a lipopolysaccharide-induced inflammatory response in human peripheral blood monocytes. Our results emphasize the need to evaluate the effects of nanomaterials in the presence of agonists (such as lipopolysaccharides) which are expected to occur in real-life conditions. In the future, further studies on primary human cells focusing on susceptible populations (with pre-existing diseases) are warranted for identification of the realistic hazards of nanomaterials.

\section{Acknowledgments}

This research was supported in part by the Intramural Research Program of the National Institute of Environmental Health Sciences. We gratefully acknowledge all volunteers who participated in this study. Shyamal Peddada is gratefully acknowledged for excellent statistical advice. We also thank Nicole Edwards and Gina Musselwhite for support in patient recruitment, and Erika Gutierrez, Connie Cummings, and Deloris Sutton for their technical assistance.

\section{Disclosure}

The authors report no conflicts of interest in this work.

\section{References}

1. Korsvik C, Patil S, Seal S, Self WT. Superoxide dismutase mimetic properties exhibited by vacancy engineered ceria nanoparticles. Chem Commun (Camb). 2007;10:1056-1058.

2. Das M, Patil S, Bhargava N, et al. Auto-catalytic ceria nanoparticles offer neuroprotection to adult rat spinal cord neurons. Biomaterials. 2007;28(10):1918-1925

3. Tarnuzzer RW, Colon J, Patil S, Seal S. Vacancy engineered ceria nanostructures for protection from radiation-induced cellular damage. Nano Lett. 2005;5(12):2573-2577.

4. Chen J, Patil S, Seal S, McGinnis JF. Rare earth nanoparticles prevent retinal degeneration induced by intracellular peroxides. Nat Nanotechnol. 2006;1(2):142-150.

5. Yu JC, Zhang L, Lin J. Direct sonochemical preparation of high-surfacearea nanoporous ceria and ceria-zirconia solid solutions. J Colloid Interface Sci. 2003;260(1):240-243.

6. Heckert EG, Karakoti AS, Seal S, Self WT. The role of cerium redox state in the SOD mimetic activity of nanoceria. Biomaterials. 2008;29(18):2705-2709.

7. Khan SB, Faisal M, Rahman MM, Jamal A. Exploration of $\mathrm{CeO}$ nanoparticles as a chemi-sensor and photo-catalyst for environmental applications. Sci Total Environ. 2011;409(15):2987-2992. 
8. Izu N, Shin W, Matsubara I, Murayama N. Development of resistive oxygen sensors based on cerium oxide thick film. Journal of Electroceramics. 2004;13:703-706.

9. Corma A, Atienzar P, Garcia H, Chane-Ching JY. Hierarchically mesostructured doped $\mathrm{CeO}_{2}$ with potential for solar-cell use. Nat Mater. 2004;3(6):394-397.

10. Kosynkin VD, Arzgatkina AA, Ivanov EN, et al. The study of process production of polishing powder based on cerium dioxide. J Alloys Compd. 2000;303:421-425.

11. Nikolaou K. Emissions reduction of high and low polluting new technology vehicles equipped with a $\mathrm{CeO}_{2}$ catalytic system. Sci Total Environ. 1999;235(1-3):71-76.

12. Park B, Donaldson K, Duffin R, et al. Hazard and risk assessment of a nanoparticulate cerium oxide-based diesel fuel additive - a case study. Inhal Toxicol. 2008;20(6):547-566.

13. Cassee FR, van Balen EC, Singh C, et al. Exposure, health and ecological effects review of engineered nanoscale cerium and cerium oxide associated with its use as a fuel additive. Crit Rev Toxicol. 2011;41(3):213-229.

14. Organisation for Economic Co-operation and Development. List of manufactured nanomaterials and list of end points for phase one of the OECD testing programme, 2008. Available from: http://www.oecd.org/ document/53/0,3746,en_2649_37015404_37760309_1_1_1_1,00.html Accessed January 30, 2012.

15. Pope CA 3rd, Thun MJ, Namboodiri MM, et al. Particulate air pollution as a predictor of mortality in a prospective study of US adults. Am J Respir Crit Care Med. 1995;151(3 Pt 1):669-674.

16. Dockery DW, Pope CA 3rd, Xu X, et al. An association between air pollution and mortality in six US cities. $N$ Engl J Med. 1993; 329(24):1753-1759.

17. Hollingsworth JW, Maruoka S, Li Z, et al. Ambient ozone primes pulmonary innate immunity in mice. J Immunol. 2007;179(7):4367-4375.

18. Hussain S, Vanoirbeek JA, Luyts K, et al. Lung exposure to nanoparticles modulates an asthmatic response in a mouse model. Eur Respir J. 2011;37(2):299-309.

19. Kamata H, Tasaka S, Inoue K, et al. Carbon black nanoparticles enhance bleomycin-induced lung inflammatory and fibrotic changes in mice. Exp Biol Med (Maywood). 2011;236(3):315-324.

20. Inoue K, Takano H, Yanagisawa R, et al. Effects of airway exposure to nanoparticles on lung inflammation induced by bacterial endotoxin in mice. Environ Health Perspect. 2006;114(9):1325-1330.

21. Inoue K, Takano H, Koike E, et al. Effects of pulmonary exposure to carbon nanotubes on lung and systemic inflammation with coagulatory disturbance induced by lipopolysaccharide in mice. Exp Biol Med (Maywood). 2008;233(12):1583-1590.

22. Hirst SM, Karakoti AS, Tyler RD, Sriranganathan N, Seal S, Reilly CM. Anti-inflammatory properties of cerium oxide nanoparticles. Small. 2009;5(24):2848-2856.

23. Niu J, Azfer A, Rogers LM, Wang X, Kolattukudy PE. Cardioprotective effects of cerium oxide nanoparticles in a transgenic murine model of cardiomyopathy. Cardiovasc Res. 2007;73(3):549-559.
24. Celardo I, De Nicola M, Mandoli C, Pedersen JZ, Traversa E, Ghibelli L. $\mathrm{Ce}(3)+$ ions determine redox-dependent anti-apoptotic effect of cerium oxide nanoparticles. ACS Nano. 2011;5(6):4537-4549.

25. Niu J, Wang K, Kolattukudy PE. Cerium oxide nanoparticles inhibit oxidative stress and nuclear factor-kappaB activation in $\mathrm{H} 9 \mathrm{c} 2$ cardiomyocytes exposed to cigarette smoke extract. J Pharmacol Exp Ther. 2011;338(1):53-61.

26. Xia T, Kovochich M, Liong M, et al. Comparison of the mechanism of toxicity of zinc oxide and cerium oxide nanoparticles based on dissolution and oxidative stress properties. ACS Nano. 2008;2(10):2121-2134.

27. Ma JY, Zhao H, Mercer RR, et al. Cerium oxide nanoparticle-induced pulmonary inflammation and alveolar macrophage functional change in rats. Nanotoxicology. 2011;5(3):312-325.

28. Cho WS, Duffin R, Poland CA, et al. Metal oxide nanoparticles induce unique inflammatory footprints in the lung: important implications for nanoparticle testing. Environ Health Perspect. 2010;118(12):1699-1706.

29. Park EJ, Choi J, Park YK, Park K. Oxidative stress induced by cerium oxide nanoparticles in cultured BEAS-2B cells. Toxicology. 2008;245(1-2):90-100.

30. Nalabotu SK, Kolli MB, Triest WE, et al. Intratracheal instillation of cerium oxide nanoparticles induces hepatic toxicity in male SpragueDawley rats. Int J Nanomedicine. 2011;6:2327-2335.

31. Gojova A, Lee JT, Jung HS, Guo B, Barakat AI, Kennedy IM. Effect of cerium oxide nanoparticles on inflammation in vascular endothelial cells. Inhal Toxicol. 2009;21 Suppl 1:123-130.

32. Celardo I, Pedersen JZ, Traversa E, Ghibelli L. Pharmacological potential of cerium oxide nanoparticles. Nanoscale. 2011;3(4):1411-1420.

33. Suri SS, Fenniri H, Singh B. Nanotechnology-based drug delivery systems. J Occup Med Toxicol. 2007;2:16.

34. Limbach LK, Li Y, Grass RN, et al. Oxide nanoparticle uptake in human lung fibroblasts: effects of particle size, agglomeration, and diffusion at low concentrations. Environ Sci Technol. 2005;39(23):9370-9376.

35. Safi M, Sarrouj H, Sandre O, Mignet N, Berret JF. Interactions between sub-10-nm iron and cerium oxide nanoparticles and $3 \mathrm{~T} 3$ fibroblasts: the role of the coating and aggregation state. Nanotechnology. 2010;21(14):145103.

36. Hussain S, Boland S, Baeza-Squiban A, et al. Oxidative stress and proinflammatory effects of carbon black and titanium dioxide nanoparticles: role of particle surface area and internalized amount. Toxicology. 2009;260(1-3):142-149.

37. Val S, Hussain S, Boland S, Hamel R, Baeza-Squiban A, Marano F. Carbon black and titanium dioxide nanoparticles induce proinflammatory responses in bronchial epithelial cells: need for multiparametric evaluation due to adsorption artifacts. Inhal Toxicol. 2009;21 Suppl 1:115-122.

38. Sanfins E, Dairou J, Hussain S, et al. Carbon black nanoparticles impair acetylation of aromatic amine carcinogens through inactivation of arylamine N-acetyltransferase enzymes. ACS Nano. 2011;5(6): 4504-4511.
International Journal of Nanomedicine

\section{Publish your work in this journal}

The International Journal of Nanomedicine is an international, peerreviewed journal focusing on the application of nanotechnology in diagnostics, therapeutics, and drug delivery systems throughout the biomedical field. This journal is indexed on PubMed Central,

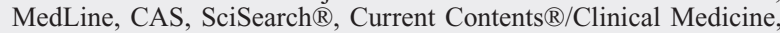

\section{Dovepress}

Journal Citation Reports/Science Edition, EMBase, Scopus and the Elsevier Bibliographic databases. The manuscript management system is completely online and includes a very quick and fair peer-review system, which is all easy to use. Visit http://www.dovepress.com/ testimonials.php to read real quotes from published authors. 